\title{
UJI AKTIVITAS ANTIDIABETES KOMBINASI GLIBENKLAMID DAN EKSTRAK DAUN SALAM (Syzygium polyanthum Wight.) TERHADAP MENCIT (Mus musculus) YANG DIINDUKSI ALOKSAN
}

\author{
ANTIDIABETIC ACTIVITY TEST OF COMBINATION OF \\ GLIBENCLAMIDE AND BAY LEAF EXTRACT (Syzygium polyanthum \\ Wight.) TO ALLOXAN INDUCED MICE (Mus musculus)
}

\author{
Steffi Liem ${ }^{1}$, Yuliet ${ }^{2}$, Akhmad Khumaidi ${ }^{2}$ \\ ${ }^{1}$ Jurusan Farmasi, Fakultas MIPA, Universitas Tadulako, Palu, Indonesia
}

Received 20 Januari 2015, Accepted 20 Februari 2015

\begin{abstract}
A B S T R A K
Penanganan umum Diabetes Melitus (DM) adalah dengan menggunakan antidiabetika oral. Obat herbal juga sering digunakan sebagai alternatif pengobatan oleh pasien. Bahkan pada beberapa kasus ditemukan pasien mengkombinasikan obat kimia dan obat herbal untuk mempercepat penyembuhan. Penelitian ini bertujuan untuk melihat efek kombinasi glibenklamid dan ekstrak etanol daun salam (EEDS) dalam menurunkan kadar glukosa darah dan menentukan dosis kombinasi yang optimal sebagai antidiabetes. Metode yang digunakan adalah induksi aloksan dengan dosis $120 \mathrm{mg} / \mathrm{kg}$ BB secara intraperitoneal. Hewan uji yang digunakan adalah mencit (Mus mucsculus) jantan yang dibagi menjadi 8 kelompok, yaitu kontrol negatif (Na CMC 0,5\%), kontrol positif (glibenklamid $0,65 \mathrm{mg} / \mathrm{kg}$ BB), kombinasi 1 (glibenklamid+EEDS $250 \mathrm{mg} / \mathrm{kg}$ BB), kombinasi 2 (glibenklamid+EEDS $500 \mathrm{mg} / \mathrm{kg} \mathrm{BB}$ ), kombinasi 3 (glibenklamid+EEDS $750 \mathrm{mg} / \mathrm{kg} \mathrm{BB}$ ), EEDS $1(250 \mathrm{mg} / \mathrm{kg}$ BB), EEDS $2(500 \mathrm{mg} / \mathrm{kg} \mathrm{BB})$, dan EEDS $3(750 \mathrm{mg} / \mathrm{kg} \mathrm{BB})$. Pengamatan terhadap penurunan kadar glukosa darah masing-masing kelompok uji dilakukan pada hari ke-7 dan ke-14 setelah hiperglikemia. Berdasarkan hasil analisis ANOVA selisih penurunan kadar glukosa darah setelah 14 hari pengamatan menunjukkan bahwa kombinasi $2(230 \pm 23,69) \mathrm{mg} / \mathrm{dL}$ dan kombinasi $3(233,75 \pm 9,93) \mathrm{mg} / \mathrm{dL}$ menurunkan kadar glukosa darah yang berbeda signifikan terhadap kontrol negatif $(4 \pm 6,82) \mathrm{mg} / \mathrm{dL}$, kontrol positif $(150,75 \pm 11,34) \mathrm{mg} / \mathrm{dL}$, kombinasi 1 $(170 \pm 10,51) \mathrm{mg} / \mathrm{dL}$, EEDS $1(134,5 \pm 4,61) \mathrm{mg} / \mathrm{dL}$, EEDS $2(151,25 \pm 6,72) \mathrm{mg} / \mathrm{dL}$, dan EEDS $3(158,75 \pm 17,64)$ $\mathrm{mg} / \mathrm{dL}$. Sedangkan kombinasi 2 dan kombinasi 3 tidak berbeda signifikan. Pemberian kombinasi glibenklamid dan ekstrak daun salam dapat menurunkan kadar glukosa darah yang lebih besar daripada sediaan tunggal glibenklamid atau ekstrak daun salam. Dosis optimal yang dapat menurunkan kadar glukosa darah adalah kombinasi 2.
\end{abstract}

Kata Kunci : Glibenklamid, Ekstrak Etanol Daun Salam, Hiperglikemia, Kadar Glukosa Darah.

\section{A B S T R A C T}

Pharmacological therapy of Diabetes Mellitus (DM) is to use antidiabetic oral. Herbal medicine are also often used as an alternative treatment by patients. Even in some cases found patients combine drugs and herbal medicine to speed up the healing of DM- This study aims to know the effects of a combination of glibenclamide and bay leaf ethanol extract (BLEE) to decrease blood glucose levels and to determine its optimal combination dose as antidiabetic. The method was inducted alloxan at dose of $120 \mathrm{mg} / \mathrm{kg} \mathrm{BW}$ intraperitoneally. The animal test used were mice which divided into 8 groups of tests, the negative control ( $\mathrm{Na} \mathrm{CMC} 0,5 \%$ ), positive control (glibenclamide $0,65 \mathrm{mg} / \mathrm{kg} \mathrm{BW}$ ), combination 1 (glibenclamide+BLEE $250 \mathrm{mg} / \mathrm{kg} \mathrm{BW}$ ), combination 2 (glibenclamide+BLEE $500 \mathrm{mg} / \mathrm{kg} \mathrm{BW}$ ), combination 3 (glibenclamide+BLEE $750 \mathrm{mg} / \mathrm{kg} \mathrm{BW}$ ), BLEE 1 (250 $\mathrm{mg} / \mathrm{kg} \mathrm{BW})$, BLEE $2(500 \mathrm{mg} / \mathrm{kg} \mathrm{BW})$, and BLEE $3(750 \mathrm{mg} / \mathrm{kg} \mathrm{BW})$. After 14 days study, data were analyzed by ANOVA showed the difference in decrease of blood glucose levels combination $2(230 \pm 23,69) \mathrm{mg} / \mathrm{dL}$ and combination $3(233,75 \pm 9,93) \mathrm{mg} / \mathrm{dL}$ were significantly different to the negative control $(4 \pm 6,82) \mathrm{mg} / \mathrm{dL}$, 
positive control $(150,75 \pm 11,34) \mathrm{mg} / \mathrm{dL}$, combination $1(170 \pm 10,51) \mathrm{mg} / \mathrm{dL}$, BLEE $1(134,5 \pm 4,61) \mathrm{mg} / \mathrm{dL}$, BLEE $2(151,25 \pm 6,72) \mathrm{mg} / \mathrm{dL}$, and BLEE $3(158,75 \pm 17,64) \mathrm{mg} / \mathrm{dL}$. While combination 2 and combination 3 were not significantly different. Combination of glibenclamide and bay leaf ethanol extract decreased blood glucose levels greater than a single dosage glibenclamide or bay leaf extract. Optimal doses decreased blood glucose levels was combination 2 .

Keywords : Glibenclamide, Bay Leaf Ethanol Extract, Hyperglycemia, Blood Glucose Level.

*Corresponding author : Steffi Liem, Steffi_liem@yahoo.com (ph: +62-852-4143-2224)

\section{PENDAHULUAN}

Diabetes Melitus (DM) atau kencing manis adalah penyakit metabolisme yang merupakan suatu kumpulan gejala yang timbul pada seseorang karena adanya peningkatan kadar glukosa darah di atas nilai normal. Penyakit ini disebabkan gangguan metabolisme glukosa akibat kekurangan insulin baik secara absolut maupun relatif (Anonim, 2013). Diabetes dapat dibagi menjadi dua grup berdasarkan kebutuhan atas insulin, yakni Diabetes Melitus tergantung insulin (IDDM/ Insulin Dependent Diabetes Mellitus atau Tipe 1) dan Diabetes Melitus tidak tergantung insulin (NIDDM/ Non-Insulin Dependent Diabetes Mellitus atau Tipe 2) (Mycek, Harvey, \& Champe, 2001).

Tindakan umum yang dilakukan dalam penanganan Diabetes Melitus tipe 2 adalah diet, gerak badan dan penurunan berat badan. Jika tindakan ini tidak atau kurang efektif untuk menormalkan glukosa darah, perlu digunakan terapi insulin, atau antidiabetika oral (ADO), atau kombinasi keduanya. Selain antidiabetika oral, pasien Diabetes Melitus tipe 2 ini juga banyak menggunakan obat herbal sebagai obat komplementer alternatif penyembuhan. Selama kurun waktu 20002006 terjadi peningkatan penggunaan obat tradisional, yang dilakukan untuk pengobatan sendiri (swamedikasi), dari $15,2 \%$ menjadi 38,3\% (Adhitia, 2012).

Terapi Diabetes Melitus yang memakan waktu lama memungkinkan terjadinya pemakaian bersama obat herbal dan antidiabetika oral. Berdasarkan penelitian di 11 Puskesmas Kota Depok 2012, dari 101 orang responden, sebanyak 52,47\% menggunakan antidiabetes herbal dan 47,53\% menggunakan ADO saja. Pasien sebanyak $54,27 \%$ sebagai pengguna antidibetes herbal, ternyata menggunakan kombinasi ADO dan antidiabetes herbal sebesar $71,70 \%$, sedangkan
$28,30 \%$ menggunakan antidiabetes herbal saja. Salah satu antidibetes herbal yang digunakan adalah daun salam (Adhitia, 2012).

Secara turun-temurun daun salam digunakan sebagai bumbu masakan dan obat tradisional dalam mengobati diabetes. Pada penelitian sebelumnya, telah terbukti bahwa ekstrak etanol daun salam pada dosis 249,6 $\mathrm{mg} / \mathrm{kg}$ BB $(34,84 \%)$ dan $499,2 \mathrm{mg} / \mathrm{kg}$ BB $(55,57 \%)$ dapat menurunkan kadar glukosa darah mencit yang diinduksi aloksan sebanding dengan glibenklamid $(51,30 \%)$ (Carolina, 2007).

Salah satu obat antidiabetes oral sintetis yang paling banyak dikenal adalah glibenklamid yang bekerja menurunkan kadar glukosa darah dengan merangsang sel beta Langerhans pankreas untuk memproduksi insulin. Penggunaan bersama antidiabetes herbal dengan obat antidiabetes oral (ADO) menimbulkan kekhawatiran munculnya efek hipoglikemik yang berlebihan atau bahkan mengurangi efek hipoglikemik obat tersebut bila digunakan secara terus-menerus.

Oleh karena itu, peneliti ingin mengetahui aktivitas antidiabetes kombinasi glibenklamid dan ekstrak daun salam (Syzygium polyanthum Wight.) terhadap mencit (Mus musculus) yang diinduksi aloksan untuk melihat efektivitas pemberian terapi kombinasi apakah semakin baik dengan berefek potensiasi, yaitu kedua obat saling memperkuat khasiatnya atau efek semakin berkurang karena terjadi interaksi obat. Serta mengetahui dosis kombinasi glibenklamid dan ekstrak daun salam yang optimal untuk menurunkan kadar glukosa mencit yang diinduksi aloksan.

\section{METODE PENELITIAN Desain Penelitian}

Penelitian ini merupakan penelitian eksperimental dengan rancangan preand post test with control group design. 


\section{Waktu dan Tempat Penelitian}

Penelitian ini dilaksanakan pada bulan Oktober sampai November 2014, bertempat di Laboratorium Farmakognosi-Fitokimia dan Laboratorium Farmakologi-Toksikologi Program Studi Farmasi, FMIPA, Universitas Tadulako.

\section{Persiapan Bahan Uji}

Bahan yang digunakan dalam penelitian ini adalah daun tanaman salam (Syzygium polyanthum Wight.) yang diperoleh dari Kabupaten Sigi, Biromaru, Palu. Determinasi tanaman dilakukan di UPT. Sumber Daya Hayati Sulawesi, Universitas Tadulako, Palu. Daun tersebut dikeringkan dengan cara diangin-anginkan, kemudian dihaluskan sampai diperoleh serbuk kering. Serbuk kering daun salam sebanyak $1 \mathrm{~kg}$ dimaserasi dengan etanol 96\% selama 3 hari, kemudian disaring. Ekstrak cair yang diperoleh diuapkan dengan alat rotavapor sampai diperoleh ekstrak kental di Laboratorium Farmakognosi-Fitokimia Program Studi Farmasi Fakultas MIPA Universitas Tadulako.

\section{Uji Penapisan Fitokimia (Harbone, 1987)}

Ekstrak daun salam yang telah didapatkan kemudian diuji kualitatif terhadap adanya senyawa flavonoid, fenolik, saponin, steroid, terpenoid, alkaloid, dan tanin di Laboratorium Farmakognosi-Fitokimia Program Studi Farmasi Fakultas MIPA Universitas Tadulako.

\section{Pengujian Aktivitas Antidiabetes}

Hewan uji yang digunakan berjumlah 32 ekor, kemudian dibagi menjadi 8 kelompok uji, dengan masing-masing kelompok berjumlah 4 ekor. Pengambilan darah dilakukan pada ekor masing-masing mencit untuk pemeriksaan kadar glukosa darah awal (baseline) untuk memastikan mencit yang digunakan normal sebelum hewan uji diberi perlakuan. Semua hewan uji diberi aloksan $120 \mathrm{mg} / \mathrm{kgBB}$ pada hari ke-4 untuk menaikkan kadar glukosa darahnya. Kemudian dilakukan pengambilan darah ke-2 pada tiap mencit untuk pemeriksaan kadar glukosa darahnya. Apabila kadar glukosa darah puasa > 200 $\mathrm{mg} / \mathrm{dL}$ maka mencit dianggap sudah mengalami hiperglikemia (Alarcon-Aguilara et al., 1998). Selanjutnya diberikan perlakuan pada hewan uji selama 2 minggu berikutnya:
1) Kelompok 1 sebagai kontrol negatif, diberikan larutan $\mathrm{Na}-\mathrm{CMC} 0,5 \%$.

2) Kelompok 2 sebagai kontrol positif glibenklamid $0,65 \mathrm{mg} / \mathrm{kgBB}$.

3) Kelompok 3 sebagai kelompok uji, diberikan kombinasi ekstrak daun salam $250 \mathrm{mg} / \mathrm{kgBB}$ dan glibenklamid 0,65 $\mathrm{mg} / \mathrm{kgBB}$.

4) Kelompok 4 sebagai kelompok uji, diberikan kombinasi ekstrak daun salam $500 \mathrm{mg} / \mathrm{kgBB}$ dan glibenklamid 0,65 $\mathrm{mg} / \mathrm{kgBB}$

5) Kelompok 5 sebagai kelompok uji, diberikan kombinasi ekstrak daun salam $750 \mathrm{mg} / \mathrm{kgBB}$ dan glibenklamid 0,65 $\mathrm{mg} / \mathrm{kgBB}$

6) Kelompok 6 sebagai kelompok uji, diberikan ekstrak daun salam $250 \mathrm{mg} / \mathrm{kgBB}$

7) Kelompok 7 sebagai kelompok uji, diberikan ekstrak daun salam $500 \mathrm{mg} / \mathrm{kgBB}$

8) Kelompok 8 sebagai kelompok uji, diberikan ekstrak daun salam 750 $\mathrm{mg} / \mathrm{kgBB}$.

Dilakukan pengambilan darah ke-3 dan ke-4 pada tiap mencit untuk melihat kadar glukosa darah pada hari ke-7 dan ke-14 setelah perlakuan.

\section{Analisis Data}

Untuk analisis data, parameter yang digunakan adalah Kadar glukosa darah yang diuji normalitasnya dengan uji Saphiro Wilk. Data dikatakan terdistribusi normal jika $\mathrm{p}>$ 0,05 . Kemudian dilanjutkan dengan uji homogenitas (uji Levene), nilai $\mathrm{p}>0,05$ berarti data yang didapatkan homogen. Selanjutnya dilakukan uji statistik One Way Anova pada taraf kepercayaan $95 \%$. Apabila ada perbedaan antar kelompok dilanjutkan dengan uji analisis Post Hoc Duncan.

\section{HASIL DAN PEMBAHASAN \\ Hasil}

Hasil rendemen yang diperoleh dari proses ekstraksi sebesar 10,14\%. Berdasarkan penapisan fitokimia yang telah dilakukan diperoleh hasil bahwa ekstrak daun salam positif mengandung senyawa flavonoid, fenolik, saponin, terpenoid, alkaloid, dan tanin, sedangkan negatif terhadap steroid. Senyawasenyawa inilah yang berperan dalam memberikan khasiat dan efek biologis.

Selama penelitian dilakukan pengamatan terhadap kadar glukosa darah mencit, baik sebelum induksi dan setelah 
hiperglikemia yang dilanjutkan dengan pemberian perlakuan selama 14 hari. Pada hari ke-0, 4, 11, dan 18 dilakukan pengukuran kadar glukosa darah dalam setiap kelompok. Data rerata kadar glukosa darah hewan uji ditampilkan pada tabel berikut

Tabel 1. Hasil Pengukuran Rerata Kadar Glukosa Darah Mencit

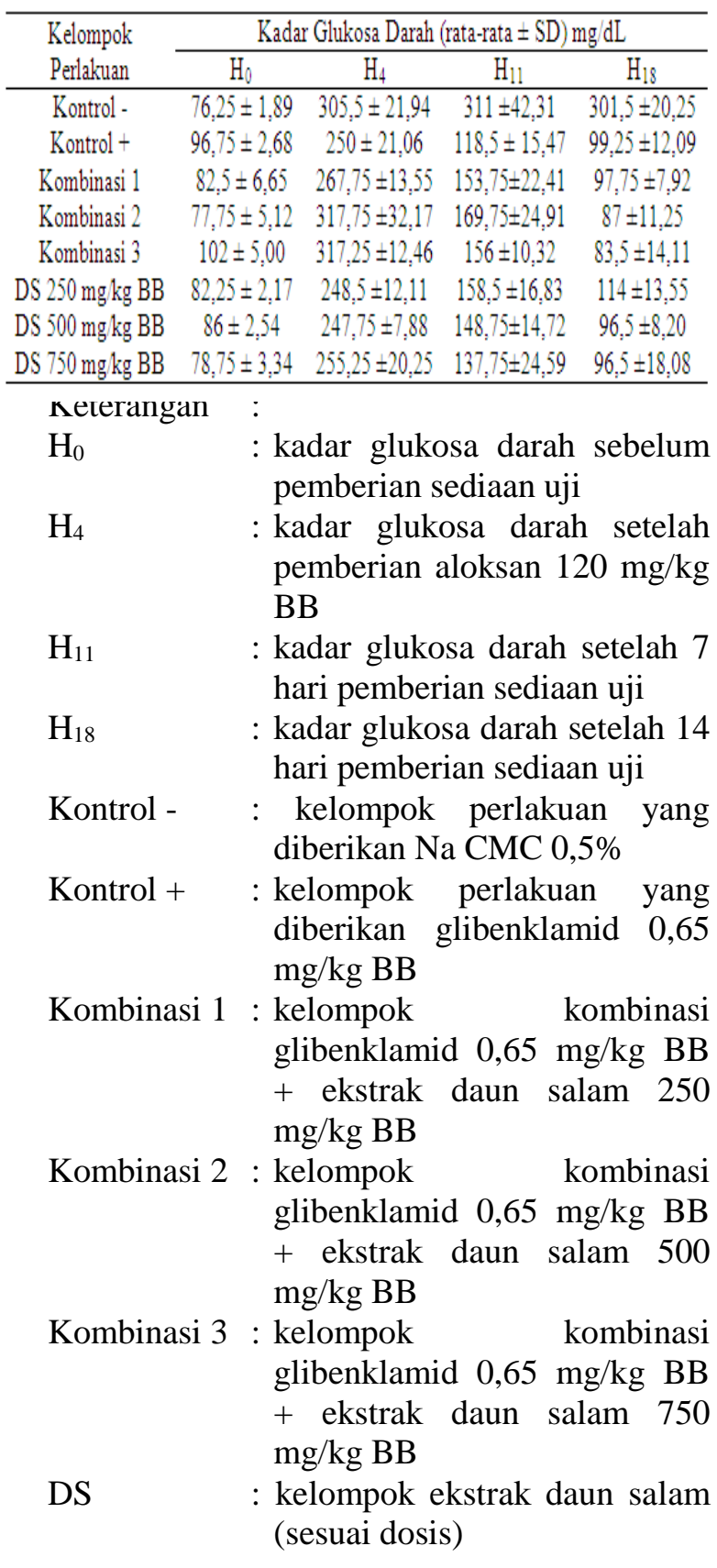

Terdapat variasi yang besar terhadap data penurunan kadar glukosa darah oleh masing-masing kelompok perlakuan, untuk melihat tingkat penurunan kadar glukosa darah yang merata, maka berikut disajikan (Tabel 2) selisih penurunan kadar glukosa darah masing- masing kelompok perlakuan terhadap hari ke-4 setelah hiperglikemia.

Tabel 2. Selisih Penurunan Rerata Kadar Glukosa Darah Mencit

\begin{tabular}{ccc}
\hline \multirow{2}{*}{ Kelompok Perlakuan } & \multicolumn{2}{c}{$\begin{array}{c}\text { Selisih Penurunan Rerata Kadar Glukosa Darah } \\
\text { (rata-rata } \pm \mathrm{SD}) \mathrm{mg} / \mathrm{dL}\end{array}$} \\
\cline { 2 - 3 } & $\Delta_{1}$ & $\Delta_{2}$ \\
\hline Kontrol - & $-5,5 \pm 21,91^{\mathrm{a}}$ & $4 \pm 6,82^{\mathrm{a}}$ \\
Kontrol + & $131,5 \pm 7,79^{\text {cd }}$ & $150,75 \pm 11,34^{\mathrm{bc}}$ \\
Kombinasi 1 & $114 \pm 9,43^{\mathrm{bc}}$ & $170 \pm 10,51^{\mathrm{c}}$ \\
Kombinasi 2 & $148 \pm 13,6^{\mathrm{da}}$ & $230,75 \pm 23,69^{\mathrm{d}}$ \\
Kombinasi 3 & $161,25 \pm 21,65^{\mathrm{a}}$ & $233,75 \pm 9,93^{\mathrm{d}}$ \\
DS 250 mg kg BB & $90 \pm 9,08^{\mathrm{b}}$ & $134,5 \pm 4,61^{\mathrm{b}}$ \\
DS 500 mg kg BB & $99 \pm 12,84^{\mathrm{b}}$ & $151,25 \pm 6,72^{\mathrm{bc}}$ \\
DS 750 mg kg BB & $117,5 \pm 25,47^{\mathrm{bc}}$ & $158,75 \pm 17,64^{\mathrm{bc}}$ \\
\hline
\end{tabular}

Keterangan :

- Abjad yang sama menunjukkan perbedaan yang tidak bermakna.

- Abjad yang berbeda menunjukkan perbedaan yang bermakna.

Grafik profil kadar glukosa darah mencit sebelum induksi (hari ke-0), setelah hipergilkemia (hari ke-4) dan setelah hari ke11 dan 18 pemberian sediaan kombinasi glibenklamid dan ekstrak daun salam serta sediaan tunggal masing-masing glibenklamid dan ekstrak daun salam dengan berbagai variasi dosis (Gambar 1) adalah sebagai berikut.

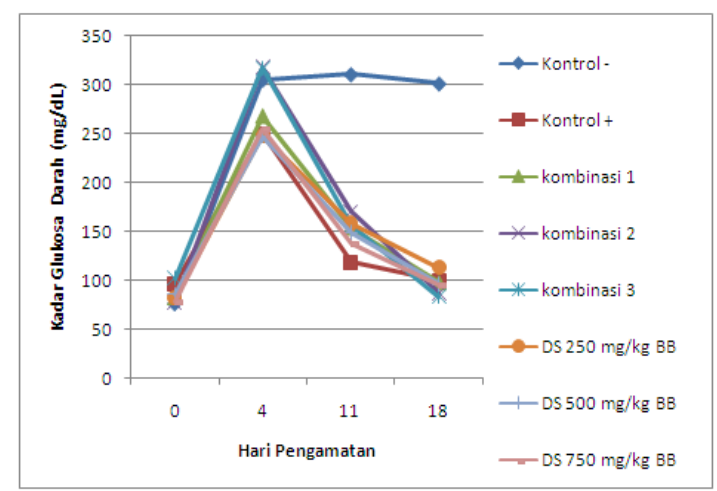

Gambar 1.Profil Rerata Kadar Glukosa Darah Pada Mencit

\section{Pembahasan}

Aloksan adalah senyawa diabetogenik karena dapat merusak sel beta pankreas dengan cara menghasilkan radikal hidroksil serta mengganggu mobilisasi ion kalsium di dalam dan di luar sel. Dua mekanisme ini mengakibatkan kerusakan terjadi baik dalam jumlah sel maupun massa sel pankreas sehingga produksi serta sekresi insulin dari sel tersebut berkurang dan menyebabkan 
penurunan sensitivitas reseptor pada sel yang memiliki reseptor insulin seperti sel otot, sel adiposa, sel hati dan sel tubuh lainnya (Lenzen \& Panten, 1998).

Pada hari ke-7 dan ke-14 setelah perlakuan kelompok kontrol positif dan kontrol uji terlihat menunjukkan penurunan kadar glukosa darah secara bertahap. Sedangkan kelompok kontrol negatif masih mengalami hiperglikemia. Penurunan kadar glukosa darah yang paling cepat terjadi pada kelompok kombinasi 2 dan kombinasi 3 dibandingkan dengan kelompok uji lainnya.

Peningkatan efek terjadi berbarengan dengan peningkatan dosis daun salam yang diberikan dalam penggunaan kombinasi. Semakin tinggi dosis yang digunakan, maka semakin besar pula efek penurunan kadar glukosa darah yang dihasilkan. Namun, hasil analisis data menunjukkan bahwa kombinasi 2 dan kombinasi 3 tidak memberikan perbedaan yang bermakna, sehingga dosis kombinasi yang optimal adalah kombinasi 2, yakni kombinasi glibenklamid dan ekstrak daun salam $500 \mathrm{mg} / \mathrm{kg} \mathrm{BB}$.

Kombinasi ekstrak daun salam memberikan efek potensiasi dengan glibenklamid dalam menurunkan kadar glukosa darah. Glibenklamid bekerja dengan merangsang sekresi insulin dari granul sel-sel beta Langerhans pankreas. Rangsangannya melalui interaksi dengan ATP-sensitive $K$ channel pada membran sel-sel beta yang menimbulkan depolarisasi membran dan keadaan ini akan membuka kanal Ca. Dengan membukanya kanal $\mathrm{Ca}$ maka ion $\mathrm{Ca}^{++}$akan masuk sel- beta, merangsang granula yang berisi insulin dan akan terjadi sekresi insulin.

Senyawa-senyawa yang terkandung di dalam ekstrak daun salam tersebut antara lain alkaloid, fenolik, flavonoid, terpenoid, tanin dan saponin. Fenolik, flavonoid, terpenoid, saponin dan tanin memiliki aktivitas sebagai antioksidan yang dapat menangkap radikal bebas yang dihasilkan dari reaksi oksidasi aloksan serta menurunkan stres oksidatif yang terjadi (Lelono \& Tachibana, 2013; Lugasi, Hovari, Sagi, \& Biro, 2003; Gwozdziewiczova, Linchnovska, Ben, Chlup, \& Hrebicek, 2005; Li \& Zou, 2009; Widowati, 2008). Alkaloid dan saponin dapat menstimulasi sekresi insulin dari sel beta pankreas (Patel, Kumar, Laloo, \& Hemalatha, 2012; Murray, Granner, Mayes, \& Rodwel, 2003). Serta terpenoid seperti triterpenoid dapat dapat meningkatkan penyerapan glukosa dengan bertindak meniru kerja insulin dan sebagai insulin sensitizer (Lee \& Thuong, 2010).

Kesimpulan yang diperoleh dari penelitian ini bahwa kombinasi glibenklamid dan ekstrak daun salam memiliki aktivitas sebagai antidiabetes terhadap mencit yang diinduksi aloksan dengan dosis kombinasi yang paling optimal adalah dosis kombinasi glibenklamid dan ekstrak daun salam 500 $\mathrm{mg} / \mathrm{kg} \mathrm{BB}$.

Oleh karena itu perlu dilakukan penelitian untuk melihat gambaran histopatologi pankreas hewan uji yang telah diberikan glibenklamid dan ekstrak daun salam untuk melihat ada tidaknya perbaikan pada sel-sel pankreas setelah pemberian aloksan.

\section{DAFTAR PUSTAKA}

Adhitia. (2012). Efek Perseptif Penggunaan Antidiabetes Herbal Bersamaan Dengan Penggunaan Obat Antidiabetes Oral Pada Pasien Diabetes Melitus Tipe 2 Di Puskesmas Kotamadya Depok. Universitas Indonesia. Jakarta.

Anonim. (2013). Hasil Riset Kesehatan Dasar 2013.

Carolina, R. (2007). Pengaruh Ekstrak Etanol Daun Salam (Polyanthi Folium) Terhadap Kadar Glukosa Darah Mencit Jantan Galur BALB/C Yang Diinduksi Aloksan. Universitas Surabaya. Surabaya.

Gwozdziewiczova, S., Linchnovska, R., Ben, R. Y., Chlup, R., \& Hrebicek, J. (2005). TNF-alpha in the Development of Insulin Resistance and Other Disorders in Metabolic Syndrome. Biomed Pap Med Fac Uni Palacky Olmouc Czech Repub, 149.

Lee, M. S., \& Thuong, P. T. (2010). Stimulation of Glucose Uptake by Triterpenoids From Weigela Subsessilis. Phytotherapy research, 24, 49-53.

Lelono, R. A. A., \& Tachibana, S. (2013). Preliminary Studies of Indonesian Eugenia polyantha Leaf Extracts as 
Inhibitors of Key Enzymes for Type 2 Diabetes. J. Med. Sci, 13(2), 103-110.

Lenzen, S., \& Panten, U. (1988). Alloxan: History and Mecanism of Action. Diabetologia, 31, 337-342.

Li, Y., \& Zou, Y. D. C. (2009). Effect of PH on Antioxidant an Antimicrobial Properties of Tea Saponins. European Food Resources Technological, 228, 1023-1028.

Lugasi, A., Hovari, J., Sagi, K. V., \& Biro, L. (2003). The Role of Antioxidant Phytonutrients In The Prevention of Disease. Acta Biologica Szegediensis, 47, 119-125.

Murray, R. K., Granner, D. K., Mayes, P. A., \& Rodwel, V. W. (2003). Biokimia
Harper (Vol. 25). Jakarta: Penerbit Buku Kedokteran EGC.

Mycek, M. J., Harvey, R. A., \& Champe, P. C. (2001). Farmakologi Ulasan Bergambar (Vol. 2). Jakarta: Widya Medika.

Patel, D., Kumar, R., Laloo, D., \& Hemalatha, S. (2012). Natural Medicines From Plant Source Used For Therapy of Diabetes Mellitus: An Overview of Its Pharmacological Aspects. Asian Pacific Journal of Tropical Disease, 239-250.

Widowati, W. (2008). Potensi Antioksidan sebagai Antidiabetes. JKM, 7(2), 1-9. 